\title{
SOCIOMETRIC STRUCTURE OF PREMIER LEAGUE VOLLEYBALL CLUB
}

\author{
Milenko Vojvodić ${ }^{1}$ and Maja Jovanović ${ }^{2}$ \\ ${ }^{1}$ Faculty of Physical Education and Sport, Univerzity of Banja Luka, Bosnia and Herzegovina \\ ${ }^{2}$ School of Mechanical Engineering, Mrkonjić Grad, Bosnia and Herzegovina
}

\section{SUMMARY}

For the investigation of interpersonal relations in small groups such as sports, sociometric procedure are used. In this study, sociometric procedure is conducted and sociometric structure has been made for the female University Volleyball Club BL volley from Banja Luka, who competes in the Premier League BiH. The task was to discover the emotional-social and functional status of the players, and the status of congruency and to evaluate the atmosphere at the club. Further analysis has been done of the aspirations of the players in terms of taking a position at the score table, as well as their assessment of management's expectations regarding the position on the score table. After sociogram and sociometric matrices has been made, it can be said that the team has three distinctive groups that are separated by mutual election of its members when it comes to emotional and sociological status. The assessment of functional status identifies two players who received 16 and 14 votes out of 17 possible. Two players who have received the most votes by socio-emotional criteria, were not selected in the first team by the coplayers, which again speaks of a team that very well makes a distinction between "friendship and business". Based on these results, it can be concluded that the atmosphere in the team is good and that it is not affected by functional status, or age of the players (almost half of the team is younger than 18). And finally, using Man-Vitni and Kruskal-Volis test it was found that neither age nor functional status does not affect significantly the assessment of the position on the score table. Functional status and age is also not a source of significant differences in the assessment of the players on what they think the club management is expected from them.

Key Words: sociometry, sociometric structure, volleyball.

\section{INTRODUCTION}

The behavior of individuals in the group, the group as a whole and relations between groups in the last few decades have become the subject of intensive study. Small groups in which interactions among members are multiple and in which members are extremely emotionally close to each other are called primary group. According to the criteria of psychological closeness and mutual influence, members of the Sports Group are one of the primary groups interactions are very numerous and varied, behavior and activity of each individual takes place under the influence of other members, and members are focused on common goals (Dunđerović, 1999). About groups and the classification of social groups also exten- sively wrote Milosavljević (2005) in his book "The social psychology of human groups." The study of interpersonal relationships deal with sociometric research first introduced in psychology by Jakob Moreno. In his research he studied the emotional relationships within the group, mutual attraction and repulsion of the group members and based on the obtained results he defined the structure of relationships in the form of sociogram. Moreno (1962), by sociometric method and its instrument (sociometric surveys, questionnaires) conducted a survey on the development and organization of the group, and the position of individuals in groups. The results of these methods are used to improve relationships in these groups, where possible, by regular and professional approach to improve the cohesion and unity of the 
group, as well as the adaptation and integration of "isolated" individuals. Sociometric methods are also used in the children's ages when it is possible to better influence on the socialization of children, and in one such study, about the creation of mutual friendships among the young children, results showed that children who have friends are better in meeting the developmental task of forming a friendship dyads and indicate a higher degree of social adaptation (Trbojević, 2014).

Klein and Christiansen (1966) have tried, with the help of sociometric methods, to choose the best five players in basketball with the help of some psychological and sociological variables. Their assumption was that it was not of primary importance to assemble a team of quality individuals, but to set up the circumstances in which individual characteristics may maximaly contribute to the final goal. Ruder and Gil (1982) have studied what are the immediate effects of lost - obtained match to the cohesion within the volleyball team. The results showed that perceptions of cohesion are under the influence of the direct effect of defeat or victory. "Group cohesion indicates the strength of connections between group members. Cohesion is much easier to achieve in smaller groups than larger. In any case, quality of interactions contributes to the cohesion of a small group, and vice versa" (Suzić, 2005, p. 245). In the paper, related to communication and sports groups (Petković, Veličković, \& Petkiović, 2013) is discusses about the factors which determine success in this groups and who depends on three types of processes that are: structuring, group processes and leadership. Structuring of the group is a process in which is determined position or place of an individual in the group. Cohesiveness is a complex feature which includes a number of group processes which have multiplier effect on the operation, and thus the efficiency of the group. Leadership represents the most distinctive feature of the group that determines the interpersonal communication (cohesiveness, communication).

In sports and sports teams cohesion or homogeneity is crucial for the success and results. There are countless examples where a set of top and "expensive players" does not give good results because of poor interpersonal relations, and vice versa, where the average quality of the team achieve great results. There are also examples where individuals, top players and key players in their clubs, changed the club, and because of the inability of integration and adaptation, due to isolation from their new teammates, they simply vanished from the sporting scene or had to change the club again. Banister says that sport is very strong verbal and nonverbal communication in its original meaning and comprehension (Banister, citated in Koković, 2001). Martinović and Barić (2012) in their work on the cohesiveness in a team sport, as an important factor for preparation, says that the degree of cohesion is best measured in the middle of the season when the team has gone through the stages of formation and excitement in the development of cohesion, but also is desirable that the measurement is done at the beginning of the preparatory period for determining the initial state of cohesion and compare with measures obtained in mid-season, in order to monitor the pace and progress of the group. As a rule, the coach has a leading influence on the behavior of his team, it is expected from him some more understanding of psychosocial interactions and behavior in a group. In order to know what kind of team it is, whether the team has split, or whether the team present opposition groups (cliques), who is respected and who is not, whether the leader (captain) is formal or informal, whether and who are isolated individuals, and so on, it is appropriate to use sociometric method (Mijanović \& Vojvodić, 2008). On some sociological relationships between coaches and players Vejnović (2006), among other things says that it is necessary to cope with problems, and solving these problems should be to the satisfaction of all, on the individual meeting in the coach office. The coach needs to know the socio-psychological reactions and interactions of his players after victory and defeat, as writen by the Puni (1966), and these findings can be obtained by sociometric research. About principles that should be followed in sociometric research Gutović (2006) has writen and emphasized the principle of information, the consent principle, the principle of confidentiality and the principle of accountability. It is clear that the practice commonly present subjective assessment of trainers on the situation within the team. Šnajder (1984) has made a sociometric analysis of volleyball team "Mladost", which at that time was one of the best teams in the former Yugoslavia, before and after important international tournaments where they achieved an excellent result. The microsocial structure of the team has very much changed after the completion of the tournament, a good result in this competition had a positive impact on interpersonal relationships within the team in the next competitive season. Marelić, Đurković, and Rešetar (2007), in the work of "Interpersonal relationships in cadet volleyball team before and after the event," says that the coach must be much more than "practitioners" and that sociometric studies can certainly confirm the coach's thoughts or initiate significant changes in the 
operation and management of the group. Sindik and Mihaljević (2011) examined the socio-economic status and the microsocial structure in the women's handball club and among others, came to the result that the players of the same socioeconomic status better emotionally accept each other. Barbaros-Tudor, Martinčević, and Novak (2010) in sociometric research at the tennis club, got results that indicate the hierarchical structure by the functional and emotional criteria.

The problem and the subject of this work are interpersonal relationships in the sports group, ie. its sociometric structure. The aim and objectives of this study was to define interpersonal relations within the team, and in order to do this it is necessary:

- To discover the mutual relations in the matter relating to socializing outside of the training and selection of a roommate at the preparations (affective expansiveness and sociodinamic effect, ie the emotional and sociological status)

- To detect functional or playing status of individuals in a team

- To detect the satisfaction of players with their status in the team (status congruency)

- To detect the views of the players about the atmosphere in their team

- To analyze the aspirations and expectations of the players and management of the club about the place in the standings at the end of the season

For this purpose to create a sociograme and index about group cohesion. One of the assumptions is that the cohesion of the team could be affect by the age of the players ( 10 out of 18 players has 20 years or less), as well as their functional status in the team and for this purpose the relationships should also be analyzed. It is interesting to analyze the relationships between functional status and age on the one hand, and estimated place by the player on the standings table (to their assessment, as well as on the assessment of what they think is a place that management expects from them) on the other.

\section{METHODS}

\section{Sample of respondents}

The sample consisted of 18 registered players of the University women's volleyball club BL Volley from Banja Luka that compete in the Premier League Bosnia and Herzegovina [BH]. They are aged 17 to 23 years and all are students at the University of Banja Luka, except the two youngest who are at the high school. It should be noted that a large number of them are from different parts of the Republic of Srpska and BH and that they simultaneously play and study. After the sociometric questionnairewas given to them, the methodology for completing was explained, as well as guarantees of anonymity.

\section{Procedure}

Sample of variables of the questions are in sociometric questionnaire, which relate to the assessment of the atmosphere at the club. Questions in sociometric instrument which are designed to measure the so-called emotional expansiveness and sociodinamičkog effect, and on which players had to answer were:

- Which teammates do you prefer to hang out after training?

- Which teammates would you select as the "roommates" in the hotel, during the preparation or stay in other cities?

The number of choices was limited to 3 , and, based on the choices following variables were constructed: number of points from sociometric matrix choice for socializing outside of training, number of points from sociometric matrix choice for "roommate" in the hotel.

In order to determine the functional (gaming) status of individual players in the team, the following choice was formulated: respondents to indicate five players with whom they would prefer to play in the lineup, in order, from best to worst. On that occasion it was determined number of points from sociometric matrix, the number of mutual choice, and the number of times someone was chosen.

To test the atmosphere within the team it was designed a five-point Likert scale where respondents were offered with five possible testimony-attitudes (strongly disagree, disagree, undecided, mostly agree, strongly agree) to assess how many players respected each other as a person, how they and the coach respect each other, how frequent are the conflicts, how much time is needed to eliminate the conflict, and in the end they generally rated the atmosphere in the team.

To determine the degree of satisfaction of their position in the team, it was designed a five-point numerical rating scale in which each of the respondents assessed their position in the team. With grade 1 respondents expressed a feeling of complete subordination to the group, grade 2 expressed partial subordination, grade 3 when respondents is and is not satisfied, or when the undecided regarding their status in the team. With grade 4 the respondents expressed 
satisfaction with the situation, a grade 5 full satisfaction of the position in the team.

Aspirations of the players, compared to the final place in the standings and their assessment, or management's expectations, are represent by two numbers with which the respondents assessed that place she expected at the end of the competition, and a place which, according to her assessment, it is expected the by the club management.

\section{Statistical analysis}

For better transparency of players interactions in the team two sociogram have been done, one social and other functional, but before that sociometric matrix is done and based on it is determined the position of each volleyball players at first and the second sociogramu. For analysis of the atmosphere within the team and determining the degree of satis- faction of players with position in the team five-point scale, was constructed, and the absolute and cumulative frequencies and percentages were determined. Whether players age (younger, older) affects on different estimates about the standings end of the season, will be determined by Man-Whitney U test.

By determining the functional status, mutual choice of players who are the best we will get three settings: the first (those players who were selected most times), the second (players with less choice) and third (players who were least chosen). Man-Whitney U test will also determine whether functional status affects volleyball player on difference choice in the assessment of the club standings at the end of the season. Does the age structure of the players and their functional status affect the atmosphere and interpersonal relationships in the team will be determined by another non-parametric methods, Kruskal-Volisov H test,

\section{FIGURE 1}

\section{Sociogram of social and emotional relationships in a team.}

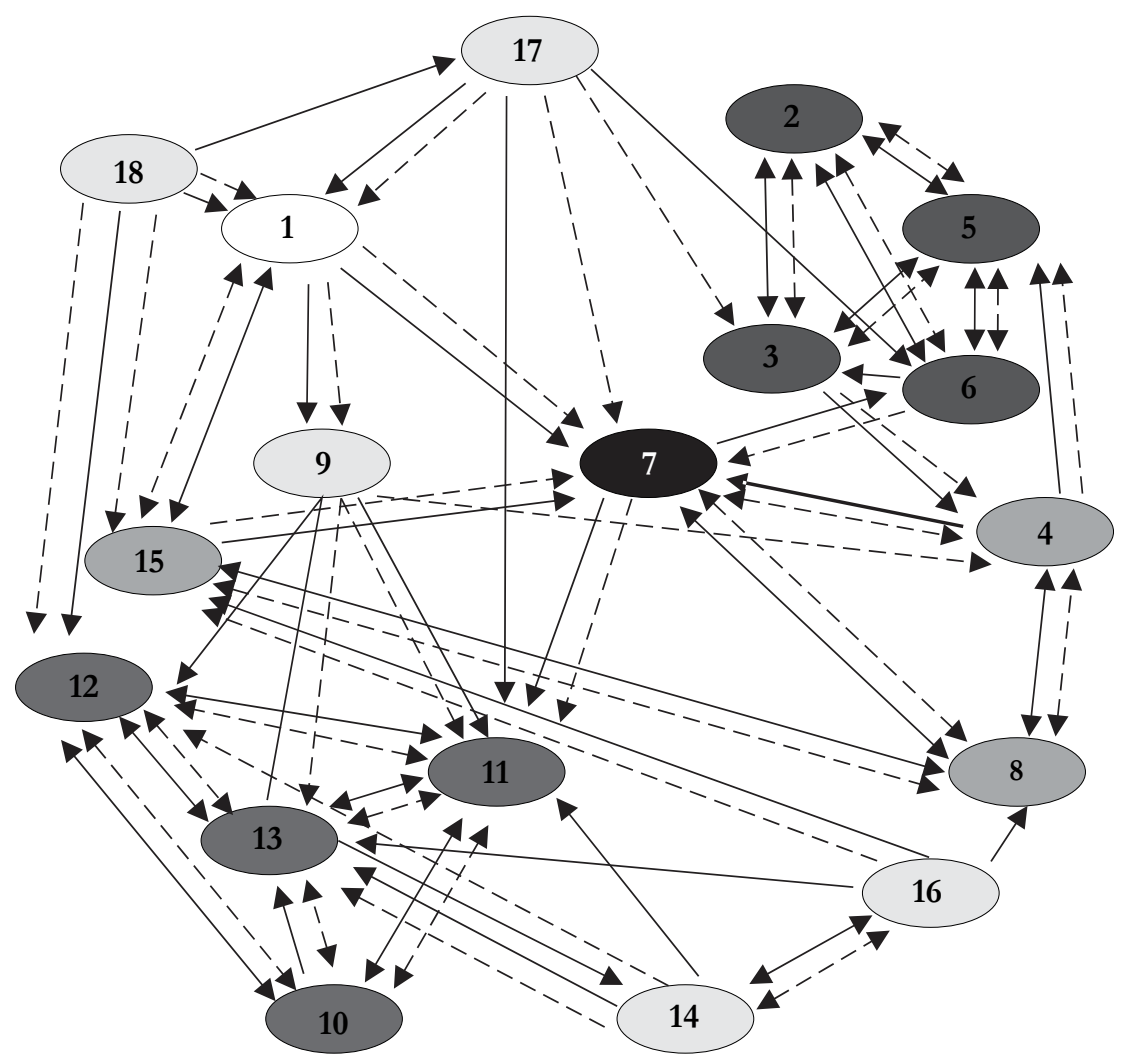

Legend:

The solid arrow in one direction is a selected teammates

with whom you preferre to hang out after training

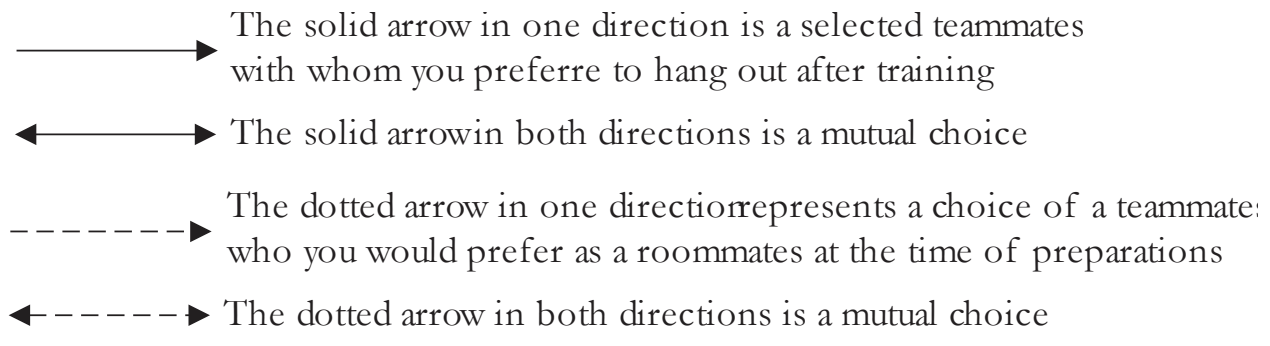


which is a nonparametric alternative analysis of variance for different groups.

\section{RESULTS AND DISCUSSION}

The first step in the analysis and consideration of interpersonal relationships in the team is analysis sociogram.

In the analysis of sociogram (Figure 1) it is immediately seen some characteristic grouping (different intensity of gray), as well as players who do not belong to any of these groups. One group consists of players $2,3,5$, and second $6,4,7,8,15$, and third players $10,11,12$, and 13 other members that are not in differentiated groups. As can be seen within the formed groups, it was largely mutual chioce for hanging off the court and being roommate in training. The players from the first group $(2,3,5,6)$ are associated with a four and a seven out of the other group over 3 and 6 . These is quite introvert group, but over players 3 and 6 still open to other teammates. The players 4,7 , and 8 out of the secong group were chosing each other on first and the second criterion, while the remaining have chosen four different players $(4 \rightarrow 5)$ from the first group, 7 selected 11 out of the third and 6 from first group, and No. 8 elected number 15 from "their" group, who again chosed number 1, which does not belong to any of these groups. Here you can confidently say that it is a ekstravertly organized group or structure where its members want to hang out in training and off with the other members of the club. Third group $(10,11,12$, and 13$)$ is the most closed and it seems self-sufficient. There is no doubt that it has introvert structure whose members want to socialize and train only with members of their group. It is obvious that when we are talking about the third group, it is a clique, so it is very interesting and that the players who do not belong to any group and having from 0 to three choices, were giving the majority of their votes to them. These are the players with numbers $(9,14,16,17,18)$. They are mostly isolated, except No. 14 who was selected from number 13 on the criteria of socializing outside the court and mutually chose with the number 16. No. 17 has only one choice and that from the number 18 who does not have one. Player number 9 has two votes from players No. 1, which also do not belong to any group and has six choices, and who, through mutual chosing with the number 15 and the double election of No. 7, is associated with the blue group. It is obvious that it is a "free shooter", but ready to cooperate.

In the end, it can be concluded on the basis of the votes counted (the election) that the players from the third group were most chosen, and the greatest number of choices (12) has received a player with the number 11, then No. 13 with 11 votes and No. 12, which has ten of the votes. However, if we take a closer look at the structure and sociogram and intercorrelation matrix (due to the size it is not placed in this paper), although they are almost completely closed, players from the third group, for some reason, have a great impact on the players who are the least selected. So number 11, which has the highest number of votes, received 4 votes from "do not belong to any group", No. 13 got 5, and No. 12 has received 3 votes. This indicates that it is popular, but less influential groups because those who gave them the most votes are less popular (not elected).

The player with a large number of votes, is number 7 out of the second group, who has 10 votes, but received by all, except the third group, although she gave two voices to No. 11 from the third group. One voice she gave to the first group which speaks of her openness to all, and popularity among all groups except in the red.

Group cohesion index was calculated by the formula:

$$
\begin{gathered}
\mathrm{IK}=\frac{\sum \sum \text { mutual choices } / 2}{\sum_{\max } \text { mutual choices }} \\
\sum_{\max } \text { mutual choices }=\frac{\max \text { choices } \mathrm{N} N}{2} \frac{3 \times 18}{2}=27 \\
\mathrm{IK}=\frac{33 / 2}{27}=.61
\end{gathered}
$$

Because the number of mutual choices was 33, and the maximum number of possible choices 54 , calculated coefficient of group cohesion is .61 so we could say that it was a good group cohesion, or cohesion which is on the border between medium and high correlation (IK $<00: 40$ - low correlation, $.40<$ IK $<.60$ - Medium, .60< IK - high correlation). Therefore, hypothesis about the possibility that a large number of young players negatively affect the cohesion of the team is waste.

Second sociogram and intercorrelative matrix (Figure 2), obtained the answer to the question with which five players would you most want to play. In this way we got first team chosed by all 18 players. They are No. 4 (which has the most choices - 16), followed by the number 2 who has 14 choices, No. 5 , who has 12 choices, and players 7,8 , and 12 , who each have 10 votes. The second setup would consist of number 13 ( 5 votes), 11 and 3, each with four votes and players 1, 6 and 9 who were selected by one. Other players were not selected at all in the first six. 
From all the above it can be concluded that mutual choices in terms of socializing outside of training and roommates in hotels (sociological status) does not affect much on the functional status of the player, or the choice in the lineup. Two players from the sociogram No.1, who had the most votes (11 and 13) now are nowhere near the first team, while the players 4 and 2 in the sociological sense a bit isolated, in functional terms are leaders in the field (4 selected 16, and 2 selected 14 times). It should be to mention

\section{FIGURE 2}

\section{Sociogram of Functional status of players.}

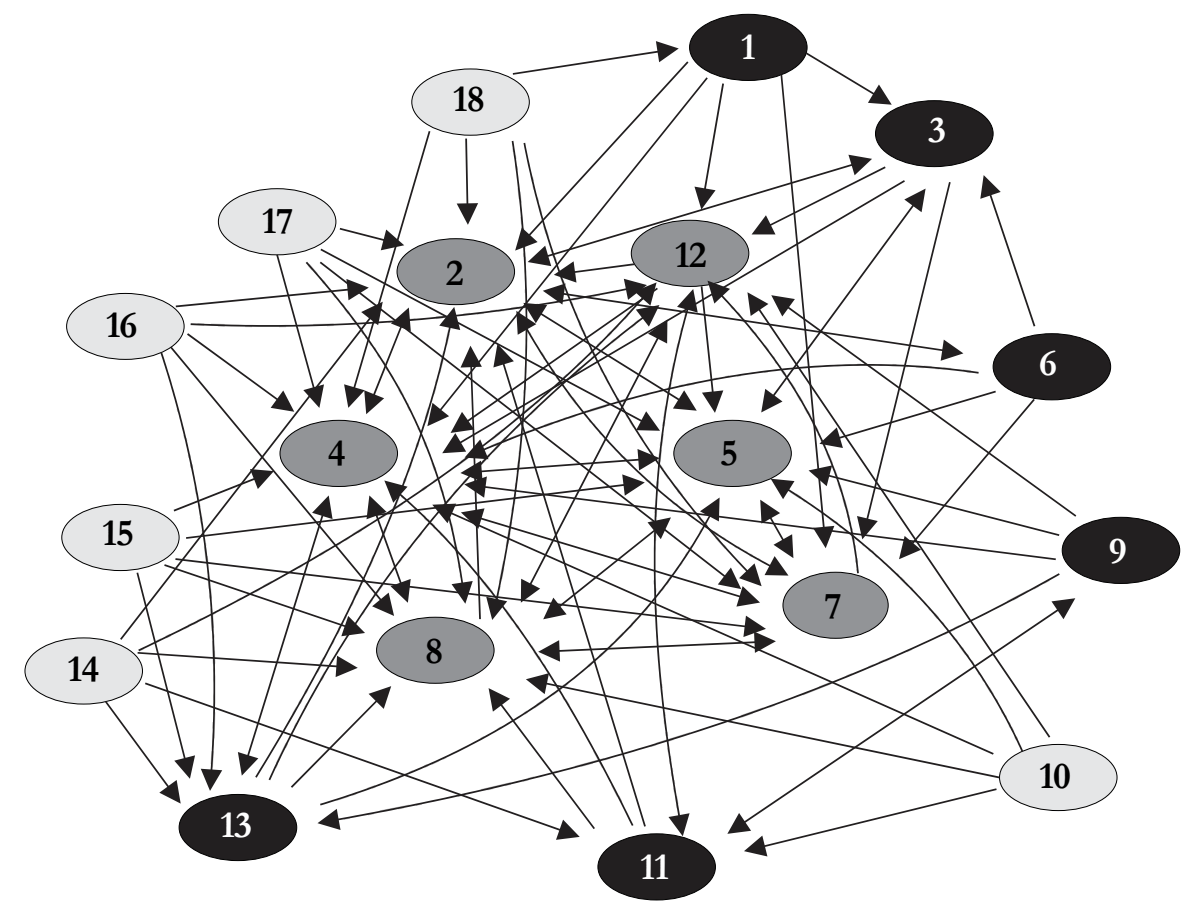

the other players who have achieved a good result in terms of the social and functional status, and these are the players with numbers $5,7,8$ and 12 , but it is necessary to emphasize that No. 7 in addition to being selected into the first line is also most open for cooperation in the sociological criteria, and she is perhaps the best solution for the team captain. On the basis of this sociogram which refers to the functional status of the players on the team, three settings can be formed: the first $(2,4,5,7,8,12)$, the other $(1,3,6,9,11,13)$ and the third $(10,14,15,16,17$, 18).

The research results related to questions about satisfaction with the status in the team showed that 12 players or slightly more than $66 \%$ of the team are happy and completely satisfied, 5 players stated that both is and is not satisfied or somewhat less than $28 \%$, while only one volleyball player feels completely subordinate, as shown in Table 1.

To the question if players respect each other, the $84 \%$ or 15 of them responded generally agree and completely agree, and three players or less than $17 \%$ were undecided in the evaluation of mutual respect.
About mutual respect between players and coaches, volleyball players have declared themselves so as of 3 or $16.7 \%$ said that they generally do not agree that the coach and the players respect each other, while 15 or $83.3 \%$ as in the previous table declared that they agree or completely agree about the comments on mutual respect. Results are in third part of Table 1.

Fourth part of Table 1 shows the results of the testimony of the players on the frequency of conflict in the team. At the conclusion that the conflicts in the team are rarity, undecided was one player, two declared to mostly disagree, 10 said they mostly agree with, a 5 to completely agree with that statement.

On the issue of conflict resolution in a team, in fifth part of Table 1 we can see that only one player was undecided, while 17 of them agreed generally and completely about the fact that if there was a conflict, they are quickly resolved.

That the atmosphere in the team is good, generaly and fully agreed 17 players, or nearly $95 \%$, and only one player has not agreed with it, as can be seen in sisxth part of Table 1. 


\section{TABLE 1}

The survey results related to the atmosphere in the team .

\begin{tabular}{|c|c|c|c|c|}
\hline & Frequency & Percent & $\begin{array}{c}\text { Valid } \\
\text { Percent }\end{array}$ & $\begin{array}{c}\text { Cumulative } \\
\text { Percent }\end{array}$ \\
\hline \multicolumn{5}{|c|}{ Satisfaction with status in the team } \\
\hline Full subordinated & 1 & 5.6 & 5.6 & 5.6 \\
\hline Yes and no satisfied & 5 & 27.8 & 27.8 & 33.3 \\
\hline Satisfied & 11 & 61.1 & 61.1 & 94.4 \\
\hline Fully satisfied & 1 & 5.6 & 5.6 & 100.0 \\
\hline Total & 18 & 100.0 & 100.0 & \\
\hline \multicolumn{5}{|c|}{ Mutual respect among players } \\
\hline Udecided & 3 & 16.7 & 16.7 & 16.7 \\
\hline Mostly agree & 12 & 66.7 & 66.7 & 83.3 \\
\hline Fully agree & 3 & 16.7 & 16.7 & 100.0 \\
\hline Total & 18 & 100.0 & 100.0 & \\
\hline \multicolumn{5}{|c|}{ Mutual respect among players and the coach } \\
\hline Generaly not agree & 3 & 16.7 & 16.7 & 16.7 \\
\hline Generaly agree & 12 & 66.7 & 66.7 & 83.3 \\
\hline Fully agree & 3 & 16.7 & 16.7 & 100.0 \\
\hline Total & 18 & 100.0 & 100.0 & \\
\hline \multicolumn{5}{|c|}{ Conflicts are rare } \\
\hline General not agree & 2 & 11.1 & 11.1 & 11.1 \\
\hline Undecided & 1 & 5.6 & 5.6 & 16.7 \\
\hline Generaly agree & 10 & 55.6 & 55.6 & 72.2 \\
\hline Fully agree & 5 & 27.8 & 27.8 & 100.0 \\
\hline Total & 18 & 100.0 & 100.0 & \\
\hline \multicolumn{5}{|c|}{ Conflicts are solved quickly } \\
\hline Undecided & 1 & 5.6 & 5.6 & 5.6 \\
\hline Mostly agree & 10 & 55.6 & 55.6 & 61.2 \\
\hline Fully agree & 7 & 38.9 & 38.9 & 100.0 \\
\hline Total & 18 & 100.0 & 100.0 & \\
\hline \multicolumn{5}{|c|}{ Atmosphere in the team is good } \\
\hline Fully disagree & 1 & 5.6 & 5.6 & 5.6 \\
\hline Generaly agree & 10 & 55.6 & 55.6 & 61.2 \\
\hline Fully agree & 7 & 38.9 & 38.9 & 100.0 \\
\hline Total & 18 & 100.0 & 100.0 & \\
\hline
\end{tabular}

As it can be seen, Man Whitney U test was "proved" that there are no statistically significant differences between younger and older players on any proposed statements about the atmosphere in the team. Most differ in their assessment is that conflicts are a rarity in the team (.203), but that is far from statistical significance. Based on these results we can rejects the assumption which speaks of the existence of differences between younger and older players in terms on the assessment of the atmosphere in the team. (Table 2).
Testing differences in the assessment of the atmosphere in the team, considering the functional status of the player, on the basis of results obtained with Kruskal Volis H test, one can conclude that the difference in functional status of the players is not the source of differences, as they were not in the previous test. The smallest difference in the assessment that the atmosphere in the team is good is .686 , and the largest in the evaluation of rare conflicts and its value is .113, which is also far from statistically significant differences, and therefore we can reject 
the second assumption which assumed that the different functional status can cause different estimates about the atmosphere at the club. (Table 3).

In the assumption was that age will not significantly affect the assessment of the players what place they will take at the end of the season, and the club management assessment of what is expected of them. Analysis of the results obtained by Man-Vitni U test showed that the players do not differ in the assessment of the position at the table for those who have aspirations, as well as in the evaluation of what place management expects from them. Results in Table 4 show that the obtained coefficients (.897 and .762) is very far from any significant differences and talk more about similarities in their assessment and thus we confirmed the assumption.

One of the tasks in this study was also to determine possible differences in the assessment of players that

\section{TABLE 2}

The differences in the assessment of the atmosphere in the team between younger and older players.

\begin{tabular}{lccrr}
\hline & Age & $N$ & \multicolumn{1}{c}{$M$} & \multicolumn{1}{c}{$\Sigma$} \\
\hline \multirow{2}{*}{ IMU } & $\mathrm{O}$ & 8 & 10.44 & 83.50 \\
\cline { 2 - 5 } & $\mathrm{Y}$ & 10 & 8.75 & 87.50 \\
\hline \multirow{2}{*}{ ITMU } & $\mathrm{O}$ & 8 & 8.56 & 68.50 \\
\cline { 2 - 5 } & $\mathrm{Y}$ & 10 & 10.25 & 102.50 \\
\hline \multirow{2}{*}{ KPR } & $\mathrm{O}$ & 8 & 11.31 & 90.50 \\
\cline { 2 - 5 } & $\mathrm{Y}$ & 10 & 8.05 & 80.50 \\
\hline \multirow{2}{*}{ KBR } & $\mathrm{O}$ & 8 & 9.69 & 77.50 \\
\cline { 2 - 5 } & $\mathrm{Y}$ & 10 & 9.35 & 93.50 \\
\hline \multirow{2}{*}{ ATD } & $\mathrm{O}$ & 8 & 10.57 & 86.00 \\
\cline { 2 - 5 } & $\mathrm{Y}$ & 10 & 8.50 & 85.00 \\
\hline
\end{tabular}

\begin{tabular}{crrrrr}
\hline & IMU & ITMU & KPR & KBR & ATD \\
\hline $\mathrm{U}$ & 32.500 & 32.500 & 25.500 & 38.500 & 30.000 \\
\hline $\mathrm{W}$ & 87.500 & 68.500 & 80.500 & 93.500 & 85.500 \\
\hline $\mathrm{z}$ & -.798 & -.798 & -1.433 & -.152 & -1.011 \\
\hline Asymp. $p$ & .425 & .425 & .152 & .879 & .312 \\
\hline Exact $p$ & .515 & .515 & .203 & .897 & .408 \\
\hline
\end{tabular}

Legend: $\mathbf{N}$ - Number of participants; $\mathbf{M}$ - Menan; $\boldsymbol{\Sigma}$ - Sum of Rnak; IMU - Mutual respect among players; ITMU - Mutual respect among players and the coach; KPR - Conflicts are rare; KBR - Conflicts are solved quickly; ATD - Atmosphere in the team is good; $\mathbf{Y}$ - Younger; $\mathbf{O}$ - Older; U - Mann-Whitney U; W - Wilcoxon W; $\mathbf{z}$ - Z score; $\mathbf{p}$ - Probability. have different functional status in the team on position at the table at the end of the season (their assessments and what management expects of them) and satisfaction with their position in the team.

Analyze of the results obtained by KruskalVolisovog $\mathrm{H}$ test undoubtedly establishes that the differences in their estimates are not statistically significant (.610 and .366), and there is no statistically significant difference in the statements on their satisfaction with the status in the team. The difference is greater than in the estimate of the position of the table, but it is not statistically significant (.182), what also confirmes that part of the assumption which refers to the functional status

\section{TABLE 3}

The differences in the assessment of the atmosphere in the team with regard to functional status in team.

\begin{tabular}{lccr}
\hline & Team & $N$ & \multicolumn{1}{c}{$M$} \\
\hline \multirow{3}{*}{ IMU } & $1^{\text {st }}$ & 6 & 8.25 \\
\cline { 2 - 4 } & $2^{\text {nd }}$ & 6 & 10.75 \\
\cline { 2 - 4 } & $3^{\text {rd }}$ & 6 & 9.50 \\
\hline \multirow{4}{*}{ ITMU } & $1^{\text {st }}$ & 6 & 7.00 \\
\cline { 2 - 4 } & $2^{\text {nd }}$ & 6 & 10.75 \\
\cline { 2 - 4 } & $3^{\text {rd }}$ & 6 & 10.75 \\
\hline \multirow{3}{*}{ KPR } & $1^{\text {st }}$ & 6 & 6.17 \\
\cline { 2 - 4 } & $2^{\text {nd }}$ & 6 & 11.33 \\
\cline { 2 - 4 } & $3^{\text {rd }}$ & 6 & 11.00 \\
\hline \multirow{3}{*}{ KBR } & $1^{\text {st }}$ & 6 & 7.92 \\
\cline { 2 - 4 } & $2^{\text {nd }}$ & 6 & 11.25 \\
\cline { 2 - 4 } & $3^{\text {rd }}$ & 6 & 9.33 \\
\hline \multirow{3}{*}{ ATD } & $1^{\text {st }}$ & 6 & 8.42 \\
\cline { 2 - 4 } & $2^{\text {nd }}$ & 6 & 10.57 \\
\cline { 2 - 4 } & $3^{\text {rd }}$ & 6 & 9.33 \\
\hline
\end{tabular}

\begin{tabular}{crrrrr}
\hline & IMU & ITMU & KPR & KBR & ATD \\
\hline$\chi^{2}$ & .944 & 2.833 & 4.357 & 1.572 & .754 \\
\hline$d f$ & 2 & 2 & 2 & 2 & 2 \\
\hline Asymp. $p$ & .624 & .243 & .113 & .466 & .686 \\
\hline
\end{tabular}

Legend: $\mathbf{N}$ - Number of participants; $\mathbf{M}$ - Mean; IMU - Mutual respect among players; ITMU - Mutual respect among players and the coach; KPR - Conflicts are rare; KBR - Conflicts are solved quickly; ATD - Atmosphere in the team is good; $\chi^{2}$ - Kruskal Wallis test; df - Degrees of freedom; $\mathbf{p}$ - Probability. 


\section{TABLE 4}

Differences in the evaluation of players due to the age, about the place in the standings at the end of the season (their assessments and what management expects from them).

\begin{tabular}{ccccc}
\hline & Age & $N$ & $M$ & $\Sigma$ \\
\hline \multirow{2}{*}{ MTABJA } & $\mathrm{O}$ & 8 & 9.69 & 77.50 \\
\cline { 2 - 5 } & $\mathrm{Y}$ & 10 & 9.35 & 93.50 \\
\hline \multirow{2}{*}{ MTABUPR } & $\mathrm{O}$ & 8 & 9.06 & 72.50 \\
\cline { 2 - 5 } & $\mathrm{Y}$ & 10 & 9.85 & 98.50 \\
\hline
\end{tabular}

\begin{tabular}{crr}
\hline & MTABJA & MTABUPR \\
\hline $\mathrm{U}$ & 38.500 & 36.500 \\
\hline $\mathrm{W}$ & 93.500 & 72.500 \\
\hline $\mathrm{z}$ & -.148 & -.331 \\
\hline Asymp. $p$ & .882 & .741 \\
\hline Exact $p$ & .897 & .762 \\
\hline
\end{tabular}

Legend: $\mathbf{N}$ - Number of participants; $\mathbf{M}$ - Menan; $\Sigma$ - Sum of Rnak; MTABJA - Assessment of the position at the table for those who have aspirations; MTABUPR - the evaluation of what place management expects from them; $\mathbf{Y}$ - Younger; $\mathbf{O}$ - Older; U - Mann-Whitney U; W - Wilcoxon W; z - ; p - Probability.

\section{CONCLUSION}

Sports teams are small groups, where members are their relatively long period together and where functional and social cohesion is crucial to the performance and success of the club. In amateur clubs social component is more emphasized, there is more orientation towards socializing and friendship, and in such areas quality relationships are higher, while the top competitive teams more accentuated functional component, where the main focus is on the victory. In this study clearly it's a team that has a good deal in the emotionally-sociological and in the functional components. Very different results in the selection of players per emotionally-sociological and functional component did not affect the cohesion and the atmosphere in the team, which speaks of the maturity of the team, or the knowledge and recognition of hierarchical structure, especially functional components. As seen from the results of research, not a very large number of young players, not functional status, are not ruining the atmosphere and cohesion of the team, nor were the source of the difference in the estimates of the position on the table. At the end of the results of this sociometric research, as well as

\section{TABLE 5}

The differences in the assessment of the players with respect to the functional status in the team, position at the table at the end of the season (their assessments and what management expects of them) and their satisfaction with the status in the team.

\begin{tabular}{cccr}
\hline & Team & $N$ & \multicolumn{1}{c}{$M$} \\
\hline \multirow{3}{*}{ MTABJA } & $1^{\text {st }}$ & 6 & 10.92 \\
\cline { 2 - 4 } & $2^{\text {nd }}$ & 6 & 8.17 \\
\cline { 2 - 4 } & $3^{\text {rd }}$ & 6 & 9.42 \\
\hline \multirow{3}{*}{ MATABUPR } & $1^{\text {st }}$ & 6 & 11.42 \\
\cline { 2 - 4 } & $2^{\text {nd }}$ & 6 & 7.33 \\
\cline { 2 - 4 } & $3^{\text {rd }}$ & 6 & 9.75 \\
\hline \multirow{3}{*}{ ZADSTATIM } & $1^{\text {st }}$ & 6 & 11.17 \\
\cline { 2 - 4 } & $2^{\text {nd }}$ & 6 & 10.67 \\
\cline { 2 - 4 } & $3^{\text {rd }}$ & 6 & 6.67 \\
\hline
\end{tabular}

\begin{tabular}{crrr}
\hline & MTABJA & MTABUPR & ZADSTTIM \\
\hline$\chi^{2}$ & .988 & 2.009 & 3.405 \\
\hline$d f$ & 2 & 2 & 2 \\
\hline Asymp. $p$ & .610 & .366 & .182 \\
\hline
\end{tabular}

Legend: N - Number of participants; $\mathbf{M}$ - Mean; MTABJA - Assessment of the position at the table for those who have aspirations; MTABUPR - the evaluation of what place management expects from them; ZADSTATIM - Satisfaction with status in the team; $\chi^{2}$ - Kruskal Wallis test; $\mathbf{d f}$ - Degrees of freedom; $\mathbf{p}$ - Probability.

other similar studies of this type, should be taken with some caution because of the honesty and openness of the respondents in answering. There is always a fear among them that others will find out the results, and the fear of knowing their own positions in the team.

\section{REFERENCES}

Barbaros-Tudor, P., Martinčević, I., \& Novak, D. (2010). The sociometric structure of a first league tennis club. In: S. Simović (Ed.), Anthropological aspects of sports, physical education and recreation (pp. 152-156). Banja Luka, Bosnia and Herzegovina: Faculty of physical education and sports. 
Dunđerović, R. (1999). Psihologija sporta [Psychology of Sport]. Banja Luka, Bosnia and Herzegovina: BL Company.

Gutović, M. G. (2006). Razvojna psihologija [Developmental psychology]. Banja Luka, Bosnia and Herzegovina: Fakultet fizičkog vaspitanja i sporta.

Klein, M., \& Christiansen, G. (1969). Group composition, group structure, and group effectiveness of basketball teams. In J. Loy and G. Kenyon (Eds.), Sport, Culture, and Society. New York, NY: MacMillan.

Koković, D. (2001). Sociologija sporta [Sociology of Sport]. Sportska akademija, Beograd

Marelić, T., Đurković, T., \& Rešetar, T. (2007). Interpersonalni odnosi kadetske odbojkaške reprezentacije prije i nakon natjecanja Interpersonal relationships cadet players of volleyball team before and after the event]. Hrvatski sportskomedicinski vjesnik, 22, 32-39.

Martinović, D., \& Barić, R. (2012). Kohezivnost u ekipnom sportu: Važan faktor sportske pripreme [Cohesiveness in a team sport: An important factor for sports training]. In D. Milanović and I. Jukić (Eds.), 10. međunarodna konferencija kondicijska priprema sportaša - Specificna kondicijska priprema (pp. 132-135). Zagreb, Craotia: Kineziološki fakultet.

Mijanović, M., \& Vojvodić, M.(2008). Metodologija antropologije sporta [Methodology of sport's anthropology] Banja Luka, Bosnia and Herzegovina: Fakultet fizičkog vaspitanja i sporta.

Milosavljević, B. (2005). Socijalna psihologija ljudskih grupa [Social psychology of human groups]. Banja Luka, Bosnia and Herzegovina: Filozofski fakultet.
Moreno, J. L.(1962). Osnovi sociometrije

[Fundamentals of sociometry]. Belgrade, Serbia: Savremena škola.

Petković, D., Veličković, S., \& Petkiović, E. (2013) Komunikacija u sportu - stručno-naučni tim [Communication in sport - professionalscientific team]. Teme, 2, 1025-1032.

Puni, A. C. (1966). Ogledi izpsihologije sporta [Essays from psychology of sport]. Belgrade, Serbia: Zavod za izdavanja udžbenika Srbije.

Ruder, M. K., \& Gill, D. L. (1982). Immediate effects of win-loss on perceptions of cohesion in intramural and intercollegiate volleyball teams. Journal of Sport \& Exercise Psychology, 4, 227-234

Sindik, J., \& Mihaljević, D. (2011). Socioeconomic status and micro-social structures within the women's handball team. SportLogia, 7(2), 151162. doi: 10.5550/sgia.110702.en.155S; doi: 10.5550/sgia.110702.se.151S

Suzić, N. (2005). Pedagogija za XXI vijek [Pedagogy for the XXI Century]. Banja Luka, Bosnia and Herzegovina: T'T-centar

Šnajder, G. (1984). Utjecaj urgentne takmičarske situacije na mikrosocijalnu strukturu jedne vrhunske odbojkaške momčadi [The impact of emergency situations competition at the microstructure of one of top volleyball team]. Kinesiology, 2: 199-205.

Trbojević, J., \& Petrović, J. (2014). Socijalne karakteristike dece koja uspostavljaju prijateljske dijade [Social characteristics of children who establish friendship dyad]. Primenjena psibologija, 7(3), 493-507.

Vejnović, D. (2006). Sociologija sporta [Sociology of Sport]. Banja Luka, Bosnia and Herzegovina: Fakultet fizičkog vaspitanja i sporta

Received: August 27, 2014 Revision received: Noveber 11, 2014 Accepted: December 13, 2014

Correspondence to: Milenko Vojvodić, $\mathrm{PhD}$ Fakultet fizičkog vaspitanja i sporta Bulevar Vojvode Petra Bojivića 1A 78000 Banja Luka

Bosnia and Herzegovina Phone: 0038765750967

Fax: 0038751312280

E-mail:milenkobl@gmail.com 